\title{
Ethical Reputation, Not Fees Drive Auditor Selection At Inc. 500 Companies
}

\author{
H. Lon Addams, (E-mail: laddams@weber.edu), Weber State University \\ Anthony Allred, Weber State University
}

\begin{abstract}
Acquiring a new client is an arduous task. Accordingly, losing an important client can be devastating to a firm and demoralizing to the accounting team assigned to the client, particularly if the client represents a significant portion of the firm's revenue stream. This research study reflects the concern of CEOs that poor customer service can result in firing the present accounting firm. Besides completing the work required by the client, the accounting firm needs to build the perception of being a problem-solver and an initiator of ideas that markedly helps a client's overall financial health and well-being. To do otherwise will result in the client putting its need for professional services "out to bid."
\end{abstract}

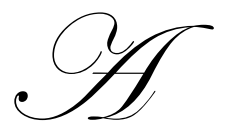

$\mathrm{n}$ audit firm's long-term survival depends on its ability to find new customers and retain existing clients. Audit firms spend considerable time and resources to improve their chances of success. Losing a client to a competitor--unless the client becomes undesirable--is simply not acceptable to an audit firm's top management. Thus, identifying the important factors that potential customers and clients use in their selecting and switching auditors is invaluable.

One audit firm's solution to the intense pressure to acquire new business and retain existing business has been to develop strategies that increase the number of small-to-medium sized firm audits. In the U.S., over 90 percent of businesses are small companies, many of which need audits--for government requirements, for equity owners, for banks, etc. The "Inc. 500" represents some of the fastest growing, small companies in the United States. Hence, audit firms, if not already doing so, should seriously consider targeting Inc. 500 type companies as part of their overall market share expansion strategy.

The recent Enron, Tyco, WorldCom, et al. debacle and related publicity have created an atmosphere of mistrust and suspicion amid a significant loss of public and customer confidence in large corporations and their audit firms. A response to the corporate scandals of the early 2000s, the Sarbanes-Oxley Act passed the Senate 97-0 and was signed by President Bush within a few weeks of being introduced, signaling increased pressure and accountability in financial statement preparation and verification. To restore consumer confidence and improve the reputation of the accounting industry, audit firms must implement significant strategies that guarantee their operations are sound and "beyond reproach."

The ethical reputation of audit firms appears to be more important than ever before. In an article titled “Accounting Profession, Heal Thyself: A Matter of Survival," Mano, Mouritsen and Swearingen (2003) contend:

The CPA profession has the potential to be the single most important player in the financial well-being of the United States of America. On the other hand, if financial statements are not truthful, the auditing profession is worthless.

Past research has analyzed and reported on the important factors used by companies in selecting and switching audit firms. These studies have examined fees, technical and industry expertise, size, and so on, but there has been little investigation into the importance of ethical reputation and its impact on selecting and switching audit firms. The purpose of this study is to examine the post-Enron and accounting firm fiascos to see if the criteria for selecting and switching 
auditors have changed. This study investigates the importance of the ethical reputation of auditors as a determining factor in selection and switching auditors. Since many audit firms are incorporating strategies that attempt to increase the number of small to medium size audits - not to mention the majority of potential customers are small companies - this study specifically examines the criteria the Inc. 500 companies use to select and switch auditors.

\section{BACKGROUND}

Addams and Davis (1993) found that managing partners of national accounting firms strongly believe that client decision-makers look at fees, industry expertise, and personal relationships with client decision-makers as the key determinants in why a firm selected a particular accounting firm. Partners and managers in accounting firms typically attribute their lack of success in obtaining a client's audit business to being "low-balled" by a competing audit firm; an expression used to describe another firm that simply under-bids in order to secure the client. Is this the real reason a potential client chooses a competing firm?

Addams and Allred (2002) set out to better understand the auditor selection and retention decision-making process used by small-but-growing private firms in the U.S. From a listing of 12 selection criteria, they found that the quality of the CPA firm's technical expertise, followed closely by the personal relationships between CPA firm's key people and the potential client's decision-makers, were the two top-ranked auditor selection factors; the proposed fee was ranked fourth. The two top-ranked auditor retention factors related to the CPA firm's ability to react swiftly to the client's needs and to provide proactive assistance to the client. The controversial factor "fees too high" was ranked fifth by responding CEOs among 11 criteria.

\section{Selection}

When it comes to selection, firms consider several factors. For example, Woo and Koh (2001) researched specifically the factors associated with auditor changes. The sample comprised 54 auditor-change Stock Exchange of Singapore (SHS) companies and 54 non-auditor-change SHS companies. Their findings provide some support to the belief that auditor changes are more likely in cases where firms engage smaller audit firms, change their management composition, experience a lower diffusion of ownership, experience an increase in income manipulation opportunities, have many subsidiaries, or have more rapid growth. Abbott and Parker (2001) found that companies with independent and active audit committees were more likely to view industry specialization by an auditor as enhancing audit quality.

A few studies have researched this interesting dilemma from slightly differing angles. For example, in a recent study, Stanny, Anderson, and Nowak (2000) surveyed 1,224 clients of a single, local accounting firm in the San Francisco Bay area. The firm provided a full range of services and the client base consisted of individuals, partnerships, corporations, and service and manufacturing entities. Clients rated 24 selection factors and 18 retention factors. The researchers found that personal integrity of the accountant, technical and industry expertise, returning of phone calls, size of the firm, partners= personalities, recommendations by others, and cost of services were the most important factors in the initial selection. Mail solicitations, yellow pages, and web pages were the least important. It should be noted, however, that this study focused on one particular accounting firm and its array of clients in single geographical area--San Francisco, which limits the ability to generalize the results of the study.

In 1996, Soo Young Kwon studied the effect of the degree of competition within the client industry on the choices of audit firms operating within that same industry. According to Kwon, when a client firm desires an audit firm not engaged with a competitor of the firm, there is a derived demand for selecting an audit firm unengaged in the client=s or potential client=s industry; surviving client firms in a particular industry do not want to risk the transfer of proprietary information to their competitors.

In an earlier 1994 study, Hermanson et. al. found that reputation was the most important criterion in the selection of an accounting firm with personnel next in importance. Fee consideration was more important to small clients. Hermanson's study was limited to auditing clients of large national accounting firms. Likewise, Rummel, Davidson and Acton (1999) found that personal integrity and meeting deadlines were key factors in a client's decision to select an accountant. 


\section{Switching}

When it comes to switching audit firms, there are a number of important criteria companies consider. One reason for changing auditors includes the desire to decrease audit fees, according to a study done by Gregory \& Collier (1996). They surmised that if the incumbent auditor of the acquiree has been charging a fee considered too high, then the acquirer is more likely to replace the new subsidiary's auditor.

Other reasons for auditor change have included the attempt to obtain more favorable audit opinions (Citron \& Taffler, 1992) and to resolve auditor-client disagreements and personality clashes (Beattie \& Fearnley, 1995). Some studies have argued that there are quality differences among audit firms and that quality is a positive function of auditor size (Simunic \& Stein, 1987).

Research cited above by Stanny et al. noted that several factors were rated as quite important for retention of an audit firm, including quality of services, personal attention, deadlines met, personal integrity of the accountant, phone calls returned, as well as technical and industry expertise.

Much of the work cited above gives some insight into factors for selection and switching; however, some of the studies are limited to a specific city area or a specific country, to clients of a specific national accounting firm, to a specific situation--such as merger/acquisition--or to public accounting firm viewpoints. Some of the studies have found some support for the importance of cost, quality of audit opinions, fees, industry specialization, and disagreement factors as drivers of auditor change. At times, the "Big Four" accounting firms have been viewed as high-quality auditors in some empirical studies, with other firms being perceived as somewhat less in quality than the "Big Four." Is size, touted by large firms, a proxy for quality and a key determinant in auditor choice? Does the cost of fees really drive the decision?

The above research lists a number of important factors business decision makers consider when they initially select or switch accounting firms. And though ethical reputation has become a critically important consideration for accounting firms and their customers, the current research offers very little insight into the role of ethical reputation in the selection and switching process. This study includes ethical reputation as a factor that may have a significant impact on the selecting and switching process, and seeks to obtain a clearer picture of the current selecting and switching criteria-since the unethical and illegal fiascos associated with Enron, Tyco, and other corporate giants, investment bankers, and major accounting firms.

This study assesses potential customer and current client desires straight from the key decision-makers- the CEOs of Inc. 500 companies. The results will be genuine and, hence, benefit accounting firm's strategic and operational planning in relation to obtaining and keeping client firms. The results provide additional insight into an accounting firm's marketing, hiring, communication skill training, technical training, quality control, and ethical practices.

\section{METHODOLOGY}

Each year Inc. Magazine selects their "Inc. 500"--the top small companies in terms of sales and other financial criteria. Surveys were sent to 250 of the Inc. 500 CEOs to rate the factors that are the most important in their choosing a particular audit firm and in their keeping an auditor. Twelve envelopes were returned for address related insufficiencies. Of the 238 potential respondents, 34 CEOs completed and returned the questionnaire. Of those CEOs who returned the survey, 19 had recently switched auditing firms. Those CEOs responded to an additional set of questions related to factors that may cause companies to switch auditors.

The background section of this paper reviewed previous research to identify important factors that influence the selection and switching of auditing firms. The background research created a solid foundation for the development of the items used in the questionnaire for this study. The questionnaire asked CEOs to rate 13 items on importance in their decision to select a certified public accounting firm for assurances, tax and other related services. The 13 items included questions about size of firm, range of services, international services, ethical reputation, written and oral proposal, 
industry and technical expertise, connections, relationships, referrals, fees, and location.

The CEOs who had recently changed accounting firms were asked to rate the importance of 11 items regarding switching CPA firms. The 11 items included questions about changing personnel, inadequate knowledge, ethical issues, new ideas, disputes, proactive service, fees, responsiveness, interpersonal clashes, communication, and rotation. The scale for each selection and switching question was anchored at " 0 " (no importance) to "6" (great importance). Please see Table 1 for selection results and Table 2 for switching results.

Table 1

\begin{tabular}{|l|c|}
\hline Inc. 500 Selection Criteria & Rating \\
\hline Ethical reputation of CPA firm & 5.15 \\
\hline The CPA firm's technical expertise & 5.06 \\
\hline The CPA firm's industry expertise & 4.88 \\
\hline The personal relationships & 4.70 \\
\hline The CPA firm's proposed fee & 4.44 \\
\hline The range of services available & 4.24 \\
\hline The formal oral presentation & 4.09 \\
\hline A recommendation from another organization & 3.91 \\
\hline The initial written proposal & 3.88 \\
\hline The size of the CPA firm & 3.85 \\
\hline The location of CPA firm & 3.56 \\
\hline CPA firm acquaintance with a key employee & 3.01 \\
\hline The availability of international services & 2.48 \\
\hline
\end{tabular}

(Scale: $6=$ great importance; $0=$ no importance)

Table 2

\begin{tabular}{|l|c|}
\hline Inc. 500 Switching Criteria & Rating \\
\hline Inadequate understanding of company & 4.55 \\
\hline Not sufficiently proactive & 4.17 \\
\hline No new ideas & 3.94 \\
\hline Inadequate communication & 3.88 \\
\hline Ethical issues & 3.80 \\
\hline Lack of responsiveness & 3.61 \\
\hline Interpersonal clashes & 3.00 \\
\hline Disputes over accounting issues & 3.00 \\
\hline Change of audit team personnel & 2.70 \\
\hline Fees too high & 2.58 \\
\hline Periodic rotation & 1.27 \\
\hline
\end{tabular}

(Scale: $6=$ great importance; $0=$ no importance)

\section{SURVEY FINDINGS}

\section{Why Client Firms Select Audit Firms}

CEOs rated 13 factors in their selection of a new audit firm. Responding to the same 0-6 scale, the CEOs rated four factors quite high, indicating a considerable importance in the selection process. The "ethical reputation of CPA firm" (5.15) was rated as most important. The "quality of the CPA firm's technical expertise" with a 5.1 rating cam in a close second. CEOs clearly draw a conclusion regarding an audit firm's reputation before hiring the audit firm; a reputation for integrity must be evident. Given the media coverage of the accounting scandals over the past two-three years surely affects the consideration of the decision-makers choosing the new audit firm. 
The "technical expertise" translates to a perceived high-quality service team assigned to the audit engagement. This factor cannot be underestimated in importance; the personnel assigned to service the client simply must have the accounting skills to perform the required audit activities. Audit firms gain reputations for certain technical skills. Additionally, CEOs and decision-makers of a client firm can scrutinize the resumes of the audit personnel, looking for appropriate credentials, involvement in constant technical training, and prior audit experience.

Likewise, the next highly rated factor "industry experience" goes hand-in-hand with "technical experience." CEOs can make judgments as to the industry expertise of those auditors who will be assigned to their firm by analyzing resumes for past audit experience in the client's industry and for training and involvement in the appropriate industry or trade associations. Thus, CEOs apparently look for a service team that not only has expertise in accounting and business operations but also has the knowledge and experience in the client's specific industry.

The fourth-highest factor was the "personal relationships established or chemistry between CPA firm's key people and our company's key decision-makers during the proposal process" indicates the necessity of truly understanding addressing the client's needs as the audit team partners and managers meet with the client firm's management during the proposal process.

Although important, the "CPA firm's proposed fee", rated at 4.44 is far from the overriding factor managing partners of CPA firms seem to believe. Apparently, CEOs consider the above four factors much more important than the "fee" factor. Some audit firms "lowball" or try to "buy the audit," which translates to the mistaken opinion that fees drive the selection process. The audit firm's ethics, technical and industry expertise, and personal relationships with the client firm appear to be the gateway to a successful proposal.

Other factors, such as range of services, quality of the written and oral presentation, size of firm, and recommendation, play meaningful parts in the selection process. Note that the often-touted "international services" of an audit firm have almost no impact on the selection decision.

\section{Why Client Firms Switch Audit Firms}

The results of the survey should assist audit firms in developing strategic, tactical, and contingency plans that ensure client retention and improve success in obtaining new customers.

Contrary to the woeful lamentation by a dismissed audit firm that "apparently, our fees were too high," our survey results indicate that the factor "fees too high for value of services received" ranked next to last of the 11 factors rated. The 2.58 rating indicates that fees charged by the audit firm were not the real issue in releasing the audit firm.

Most notably, the number one reason for not retaining an audit firm was "inadequate understanding of our business." It appears that the audit team assigned to the client did not have the appropriate knowledge of the company's business activities and perhaps failed to truly understand the company's business activities.

In fact, the top three reasons have overtones that the audit firm personnel did little to engage the client in discussions regarding new methods of operations and improved ways to conducting their business. Note that "Not sufficiently proactive" was number two (4.17) of the 11 factors, followed closely by the perception that they offered "no new ideas" (3.94). Also, the factor "inadequate communication" received a 3.89 rating, indicating that the audit team could have done a much better job of informing and discussing critical aspects of the audit as it progressed. Similarly, the 3.61 rating of "lack of responsiveness of CPA firm drives additional nails in the coffin of the present audit team.

Together, the highest-rated factors paint a revealing picture: the responding CEOs were not impressed with the audit firm's ability to help them improve profitability through various technological improvements, management initiatives, or other improved efficiencies. In short, the audit staff--from staff accountant to audit partner--failed to add any insights to improve the company's overall health. 
Ethics did play a meaningful part in decisions to release auditors. The "ethics" factor at 3.80 followed closely behind "inadequate communication." Apparently, certain ethical issues regarding the CPA firm arose during the engagement or the factor would not have been rated so high. It is apparent that the issue of ethics plays a meaningful part in the decision to keep a present audit firm on board.

\section{Implications}

With the intense competition for new clients, accounting practitioners must consider the client firm's needs very carefully. They must be able to communicate through words and actions that they are not only technically qualified but also can provide premier customer service. Perhaps, most importantly, they need to acquire a reputation of being ethical. "Totally ethical" should be the type of comment permeating the halls of corporate America when an audit firm's name is discussed. Training programs within a firm should spend significant time in their workshops addressing ethical situations and accompanying ethical behavior. Technical and industry expertise must receive constant attention, since a client firm demands such expertise.

The bidding firm must improve the oral and written communication skills of their professionals. During the proposal process, they must interact often with the client personnel, in a sincere effort to understand the client's needs. Besides the interactions on the phone, email, and in person, they must expertly present their company's image, skills, and attitudes in the written proposal and oral presentation to the client's decision-makers. Thus, accounting firms should spend quality time to hire college graduates with excellent communication skills and to train their staff and managers in the art of customer service.

A final recommendation relates to the college education of a graduating accounting major. Professors responsible for curriculum in accounting degree programs should consider these findings in light of the need for ethics, customer service, and communication skills in the proposal process and the engagement work. Too often, accounting degree programs do not place sufficient emphasis and training on these skills. Further, in-house training should be programmed in such a way that periodically (every quarter or semi-annually) the accounting firm provides their own ethics and customer service workshops. Building a reputation of trust and impeccable character of the accounting firm's professionals will carry an accounting firm through the economic whims of the future.

\section{REFERENCES}

1. Abbott, Lawrence J. and Parker, Susan, (2001), “Audit Committees and Auditor Selection”, Journal of Accountancy, vol. 191, Issue 6, 95.

2. Addams, H. Lon and Allred, Anthony, (2002), "Auditing: Why the Fastest Growing Companies Hire and Fire Their Auditors", The CPA Journal, LXXII/No. 5 (May), 62-63.

3. Addams, H. Lon and Davis, Brian, (1993), "Managing Partners Share Marketing Insights BLowballing is Not Enough", Public Accounting Report, January 15 issue, 3.

4. Beattie, V. \& Fearnley, S. (1995), 'The Importance of Audit Firm Characteristics and Drives of Auditor Change in UK Listed Companies", Accounting and Business Research 25, 227-239.

5. Citron, D.B. and Taffler, R. (1992), "The Audit Report Undergoing Concern Uncertainties: An Empirical Analysis", Accounting and Business Research, 22: 337-345.

6. Gregory, A. and Collier, P. (1996), "Audit Fees and Auditor Change: An Investigation of the Persistence of Fee Reduction by Type of Change", Journal of Business Finance and Accounting, 23, 13-28.

7. Hermanson, R.H., Plunkett, L.M., and Turner, D.H., (1994), "Study of the Importance of Certain Attributes to Client's Initial Selections of Audit Firms: A Longitudinal and Stratified Approach", Journal of Applied Business Research; (winter), 101-113.

8. _How the 2000 Inc. 500 Were Selected", Inc. Magazine, 161, Oct. 17, 2002.

9. Kwon, Soo Young, (1996), "The Impact of Competition Within the Client's Industry on the Auditor Selection Decision", Auditing, vol. 15, Issue 1, 53-71.

10. Mano, Ronald M., Mouritsen, Matthew L., and Swearingen James G., (2003), “Accounting Profession, Heal Thyself: A Matter of Survival," The CPA Journal, (August), 6-9. 
11. Rummel, A., Davidson, S.M. and Acton, D. (1999), "Getting New Clients and Keeping Old Clients, The CPA Journal, 69 (April), 56-57.

12. Stanny, E., Anderson, S., and Nowak, L., (2000), "Contributing Factors in the Selection and Retention of Local Accounting Firms", The National Public Accountant, 45, issue 4, 19-21.

13. Simunic, D. A., and Stein, M. 1987, Production Differentiation in Auditing: A Study of Auditor Choice in the Market for Unseasoned New Issues. Vancouver, BC: Canadian Certified General Accountants' Research Foundation.

14. Woo, E-Sah and Koh, Hian Chy, (2001), "Factors Associated with Auditor Changes: A Singapore Study", Accounting \& Business Research, (spring), vol. 31, Issue 2, 133-145.

\section{NOTES}


NOTES 